\title{
A Study of Otologic Symptoms and Prognosis in Patients With Ramsay Hunt Syndrome and Bell's Palsy
}

\author{
Soo Young Choi ${ }^{1} \mathbb{D}$, Tong In $\mathrm{Oh}^{2}{ }^{\mathbb{D}}$, Eun Hye Lee ${ }^{3}$ (D) Jae Min Lee ${ }^{1}$, Gang Won Choi ${ }^{1}$, \\ Hyun Ji Lee ${ }^{1}$, Sang Hoon Kim ${ }^{1}{ }^{1 D}$, and Seung Geun Yeo ${ }^{1}$ (D) \\ Departments of ${ }^{1}$ Otorhinolaryngology-Head and Neck Surgery, ${ }^{2}$ Biomedical Engineering, and ${ }^{3}$ Pediatrics, College of Medicine, \\ Kyung Hee University, Seoul, Korea \\ 이성대상포진과 벨마비 환자에서 이과적 증상과 예후에 관한 연구 \\ 최수영 ${ }^{1} \cdot$ 오동인 $^{2} \cdot$ 이은혜 ${ }^{3} \cdot$ 이재민 $^{1} \cdot$ 최강원 $^{1} \cdot$ 이현지 $^{1} \cdot$ 김상훈 $^{1} \cdot$ 여승근 $^{1}$ \\ 경희대학교 의과대학 ${ }^{1}$ 이비인후과교실, ${ }^{2}$ 의공학교실, ${ }^{3}$ 소아청소년과학교실
}

Received September 23, 2020

Revised February 2, 2021

Accepted March 8, 2021

Address for correspondence

Seung Geun Yeo, MD, PhD

Department of Otorhinolaryngology-

Head and Neck Surgery,

College of Medicine,

Kyung Hee University,

Kyung Hee University Hospital,

23 Kyungheedae-ro,

Dongdaemun-gu,

Seoul 02447 , Korea

Tel $+82-2-958-8980$

Fax $+82-2-958-8470$

E-mailyeo2park@gmail.com
Background and Objectives Although several studies have compared the characteristics of Ramsay Hunt syndrome (RHS) with Bell's palsy (BP), the differences in comorbid symptoms and prognosis according to symptoms have not been determined. This study therefore evaluated the differences in otologic symptoms and prognosis between patients with these two conditions.

Subjects and Method The medical records of 118 patients with RHS and 215 patients with BP were retrospectively reviewed. Factors compared in these two groups included otologic symptoms, general health condition, electroneurography (ENoG) and House-Brackmann grades. Results Age, sex, body mass index, lipid profiles, ENoG, rate of diabetes, and side of palsy did not differ significantly between patients with RHS and BP $(p>0.05)$. The rates of hearing disturbance, tinnitus, vertigo, and postauricular pain were significantly higher in RHS $(p<0.05$ each). Hearing disturbance was more frequent in patients with severe Bell's facial palsy than with moderate Bell's facial palsy $(p<0.05)$. The prognosis of patients with BP and RHS who had otologic symptoms did not differ from those who had not $(p>0.05)$. Additionally, in patients with facial paralysis, diabetes was associated with hearing disturbance and vertigo symptoms and dyslipidemia was associated with postauricular pain $(p<0.05$ each).

Conclusion Otologic symptoms were more common in RHS than in BP. However, the prognosis of RHS and BP were not related to otologic symptoms. In patients with facial palsy hearing disturbance and vertigo were associated with diabetes and hypertension. Also, dyslipidemia was associated with post auricular pain.

Korean J Otorhinolaryngol-Head Neck Surg 2022;65(5):260-7

Keywords Bell palsy; Prognosis; Ramsay Hunt syndrome.

\section{서 론}

말초성 안면마비의 대표적인 질환으로는 벨마비(Bell's palsy)와 이성대상포진(Ramsay Hunt syndrome)이 있고, 이들

This is an Open Access article distributed under the terms of the Creative Commons Attribution Non-Commercial License (https://creativecommons.org/licenses/by-nc/4.0) which permits unrestricted non-commercial use, distribution, and reproduction in any medium, provided the original work is properly cited.
은 각각 단순포진바이러스(herpes simplex virus)와 수두대 상포진바이러스(varicella zoster virus)에 의해 발병하는 것 으로 알려져 있다.,2) 벨마비는 약 $70 \%$ 정도가 후유증 없이 잘 회복되고 $80 \%$ 이상이 만족스러운 결과까지 회복되지만,34 이성대상포진은 일반적으로 벨마비보다 예후가 나쁘다고 알 려져 있다.5 안면마비의 발생이나 완전한 회복이 안될 경우 환자에게 상당한 심리적 압박감을 주기에, 조기에 완전 회복 
이 중요하다. 따라서 안면마비가 발병 후 완전 회복에 대한 예 후를 아는 것은 환자 치료와 상담에 중요하고, 이에 안면마비 의 예후를 예측하기 위한 많은 연구들이 진행되어 왔다.)

말초성 안면마비 환자들에게 안면마비 이외에 청력저하 (hearing disturbance), 어지러움(vertigo), 이충만감(earfullness), 이통(otalgia) 등의 이과적 증상들이 동반될 수 있다.8) 하지만 안면마비 환자에게 이런 이과적 증상들이 안면마비의 중증도에 따라 얼마나 나타나는지, 그리고 예후와 어떤 연관 성이 있는지에 관해 아직 명확하게 연구된 바가 없었다. 또한 안면마비 환자에서 당뇨병 또는 고혈압 등의 기저질환력에 따라 예후에 차이가 있다는 연구들이 있었지만, 이과적 증상 들이 기저질환 동반 유무에 따라 어떤 차이가 있는지도 연구 된 바가 없었다. ${ }^{9}$

따라서 본 연구는 첫째로, 벨마비와 이성대상포진에 따라 청력저하, 이명, 청각과민(hyperacusis), 어지러움, 후이개 통 증(postauricular pain) 등의 이과적 증상들의 차이점이 있는 지를 알아보았다. 둘째로, 안면마비의 중증도에 따라 이과적 증상의 차이를 알아보고, 이런 증상들이 있을 때 안면마비 회복률에 차이가 있는지 알아보았다. 마지막으로, 안면마비 환자에서 고혈압, 당뇨, 비만, 이상지질혈증 등이 있을 때 각 각의 청력저하, 이명, 청각과민, 어지러움, 이통 등의 증상 발 생에도 차이가 있는지를 분석하였다.

\section{대상 및 방법}

\section{대 상}

2007년부터 2019년까지 경희대학교병원 이비인후과에 벨 마비 환자와 이성대상포진 환자 각각 215명, 118명을 대상으 로 후향적 차트리뷰를 통해 연구를 진행하였다. 뇌병변에 의 한 안면마비, 외상에 의한 안면마비 등 다른 원인으로 인한 안면마비는 제외되었다. 이비인후과 전문의에 의해 다른 원 인이 확인되지 않은 안면마비 환자를 벨마비로, 안면마비와 함께 피부발진과 수포 등의 피부병변과 이통이 있는 경우 이 성대상포진으로 진단하였다.

\section{방 법}

모든 환자들은 이비인후과 전문의에 의해 내원 당시 initial House-Brackmann grade를 평가받았고, 1년 이내에 마지막 으로 외래에 내원하여 final House-Brackmann grade를 재 평가 받았다. 키(height), 체중(weight), 체질량지수(body mass index, BMI), 당뇨병, 고혈압을 포함한 기저력과 혈액검사로 혈중지질농도(triglycerides, high density lipoprotein-cho- lesterol, and low density lipoprotein-cholesterol)를 알아보 았다. 안면마비의 시작일로부터 5일째 되는 날에 신경전도검 사(electroneurography, ENoG)를 시행하였다. 또한, 모든 환 자들에게 청력저하, 이명, 청각과민, 어지러움, 이통 등 다양 하게 호소하는 이과적 증상들을 물어보고 상세히 기록하였 다. 이는 의학적 진단으로서의 난청 등 객관적으로 측정된 결 과들이 아니고 환자의 주관적인 증상을 바탕으로 하였다.

Initial House-Brackmann grade는 grade IV 이하를 moderate facial palsy로, V, VI를 severe facial palsy로 정의하 였다. Final House-Brackmann grade는 I, II인 경우를 favorable recovery로, III 이상을 unfavorable recovery로 정 의하였다.

측정된 혈압이 $130 / 85 \mathrm{~mm} \mathrm{Hg}$ 이상이거나, 고혈압으로 진 단받거나 약을 복용 중인 경우 고혈압군으로 분류하였다. 공 복혈당이 110 이상인 경우, 혈액검사상 당화혈색소 $6.5 \%$ 이 상인 경우, 또는 기존에 type 2 당뇨병으로 진단받은 경우 당 뇨군으로 분류하였다. 혈중 triglyceride의 수치가 $150 \mathrm{mg} / \mathrm{dL}$ 이상이거나, high density lipoprotein (HDL)-cholesterol 수 치가 남자의 경우 $40 \mathrm{mg} / \mathrm{dL}$ 미만, 여자의 경우 $50 \mathrm{mg} / \mathrm{dL}$ 미 만일 때 이상지질혈증군으로 분류하였다. 체질량지수(BMI) 가 25 이상인 경우 비만군으로 정의하였다. ${ }^{10-12)}$

벨마비 환자와 이성대상포진 환자 모두 입원하여 스테로이 드 및 항바이러스제 병합요법 치료를 하였다. 스테로이드는 prednisolone과 methylprednisolone을 사용하였으며, prednisolone의 경우 $80 \mathrm{mg} / \mathrm{day} 4$ 일, $60 \mathrm{mg} /$ day 2 일, $40 \mathrm{mg} / \mathrm{day}$ 2일, $20 \mathrm{mg}$ /day 2일, $10 \mathrm{mg} /$ day 2일로 복용하였으며, methylprednisolone의 경우 $64 \mathrm{mg} / \mathrm{day} 4$ 일, $48 \mathrm{mg} / \mathrm{day} 2$ 일, 32 $\mathrm{mg} / \mathrm{day} 2$ 일, $16 \mathrm{mg} / \mathrm{day} 2$ 일, $8 \mathrm{mg} / \mathrm{day} 2$ 일로 복용하였다. 또한, famciclvocir $750 \mathrm{mg}$ 을 7일간 스테로이드와 함께 복용 하였다.

\section{통계 분석}

통계 분석은 SPSS 프로그램(version 20.0, IBM Corp., Armonk, NY, USA)을 이용하여 자료를 분석하였으며, MannWhitney U test, chi-square test, Fisher's exact test, multivariate logistic regression analysis 등의 방법으로 유의성 을 검정하였다. $p$-values가 0.05 미만인 경우 통계학적으로 유의하다고 평가하였다.

본 연구는 경희대학교병원 임상시험심사위원회의 심의 및 승인을 받았다(IRB No. 2019-07-065). 


\section{결 과}

이성대상포진 환자와 벨마비 환자 간 나이, 성별, $\mathrm{ENoG}$, 체 질량지수(BMI), 중성지방(triglyceride), 고밀도지단백질(HDL), 당뇨 유병률, 마비 발병 방향 모두 두 군 간 유의한 차이는 없 었다 $(p>0.05)$. 하지만 벨마비 환자군에서 이성대상포진 환자 군보다 고혈압 유병률이 유의하게 높았다 $(p<0.05)$. 이과적 증 상을 비교해 봤을 때 청력저하(hearing disturbance), 이명 (tinnitus), 어지러움, 후이개 통증 등의 호소가 이성대상포진 군에서 유의하게 높았다 $(p<0.05)$. 청각과민은 두 군에서 총 8 명 밖에 호소하지 않아서 유의성 검정은 시행하지 않고 통 계만 기록하였다(Table 1). 추가적으로 청력저하를 호소하는 환자 50 명 중 순음청력검사상 $25 \mathrm{~dB}$ 이상으로 측정되고 안 면마비가 있는 측과 없는 측의 청력 차이가 $10 \mathrm{~dB}$ 이상 차이 가 나는 환자는 15 명이었다. 이들은 이전에 돌발성 난청, 중이 염 등의 기왕력을 가진 환자들도 있었고, 원인은 알 수 없지 만 오래전부터 청력저하가 있었던 환자들도 있었다. 안면마비 이전의 청력검사 결과는 없어, 안면마비가 발병하면서 실제로 더 청력저하가 생겼는 지는 알 수 없었다.

벨마비와 이성대상포진을 각각 구분하여 안면마비의 중증 도에 따라 이과적 증상의 차이를 비교하였다. 이성대상포진군 에서는 안면마비의 중증도와 이과적 증상들과의 어떤 유의 미한 차이는 없었지만, 벨마비군에서 청력 저하는 moderate facial palsy 환자군보다 severe facial palsy 환자군에서 유의 하게 더 많이 호소하였다(18.7\% [14/75] vs. 9.3\% [13/140], $p<$ 0.05). 이와는 반대로, 이명, 어지러움, 후이개 통증 등은 moderate facial palsy 환자군과 severe facial palsy 환자군 사이 에 유의미한 차이는 없었다(Table 2).

벨마비와 이성대상포진 환자군에서 각각 청력 저하, 이명, 어지러움, 후이개 통증 등 이과적 증상 동반 여부가 예후에 어떤 영향을 미치는지 알아보았을 때, 이런 증상의 동반 여부 와 말초성 안면마비의 예후 사이에는 유의미한 연관성은 없 었다(Table 3).

말초성 안면마비 환자가 고혈압, 당뇨, 비만, 이상지질혈증 등이 있을 때 이과적 증상들이 더 잘 동반되는지 여부를 알 아보았다. 말초성 안면마비 환자 중 이성대상포진 환자군과 벨마비 환자군 모두에서 당뇨가 있을 때 유의미하게 청력 저 하를 더 많이 호소하였다. 고혈압이 있는 환자군에서 고혈압 이 없는 환자군보다 청력저하를 더 많이 호소하는 경향이 있 었으나 유의미한 차이는 아니었다. 또한, 벨마비 환자군에서 당뇨가 있을 때 어지러움을 유의미하게 많이 호소하였고, 이 상지질혈증이 있을 때 후이개 통증을 유의미하게 더 많이 동 반하였다(Table 4).

Table 1. Demographic and clinical characteristics of patients with RHS and BP

\begin{tabular}{|c|c|c|c|}
\hline & RHS $(n=118)$ & $B P(n=215)$ & $p$-value \\
\hline Age, years & $45.26 \pm 16.23$ & $43.68 \pm 19.67$ & 0.456 \\
\hline Sex & & & 0.464 \\
\hline Male & $44(37.3)$ & $89(41.4)$ & \\
\hline Female & $74(62.7)$ & $126(58.6)$ & \\
\hline Electroneurography, \% & $49.46 \pm 25.77$ & $51.99 \pm 27.21$ & 0.419 \\
\hline Body mass index, $\mathrm{kg} / \mathrm{m}^{2}$ & $23.68 \pm 3.88$ & $23.76 \pm 4.26$ & 0.858 \\
\hline Triglycerides, mg/dL & $138.88 \pm 100.36$ & $142.29 \pm 105.26$ & 0.782 \\
\hline $\mathrm{HDL}-\mathrm{C}, \mathrm{mg} / \mathrm{dL}$ & $51.73 \pm 13.88$ & $52.63 \pm 15.22$ & 0.717 \\
\hline Diabetes & $16(13.6)$ & $34(15.8)$ & 0.582 \\
\hline Hypertension & $13(11.0)$ & $46(21.4)$ & 0.018 \\
\hline Side & & & 0.475 \\
\hline Right & $63(53.4)$ & $106(49.3)$ & \\
\hline Left & $55(46.6)$ & $109(50.7)$ & \\
\hline \multicolumn{4}{|c|}{ Audiological manifestations } \\
\hline Hearing disturbance & $24(20.3)$ & $26(12.1)$ & 0.044 \\
\hline Tinnitus & $24(20.3)$ & $20(9.3)$ & 0.004 \\
\hline Hyperacusis & $2(1.7)$ & $6(2.8)$ & N/A \\
\hline Vertigo & $25(21.2)$ & $17(7.9)$ & $<0.001$ \\
\hline Postauricular pain & $76(64.4)$ & $70(32.6)$ & $<0.001$ \\
\hline
\end{tabular}

Results reported as mean \pm standard deviation or $n$ (\%). RHS, Ramsay Hunt syndrome; BP, Bell's palsy; HDL-C, high density lipoprotein-cholesterol; N/A, not applicable 
Symptoms and Prognosis in Facial Palsy I Choi SY, et al.

Table 2. Comparison of differences in incidence of otologic symptoms according to severity in patients with RHS and BP

\begin{tabular}{|c|c|c|c|c|c|c|}
\hline & \multicolumn{3}{|c|}{ RHS $(n=118)$} & \multicolumn{3}{|c|}{$\mathrm{BP}(\mathrm{n}=215)$} \\
\hline & $\begin{array}{c}\text { Moderate } \\
\text { facial palsy } \\
(n=69)\end{array}$ & $\begin{array}{c}\text { Severe } \\
\text { facial palsy } \\
(n=49)\end{array}$ & p-value & $\begin{array}{c}\text { Moderate } \\
\text { facial palsy } \\
(n=140)\end{array}$ & $\begin{array}{c}\text { Severe } \\
\text { facial palsy } \\
(n=75)\end{array}$ & p-value \\
\hline Hearing disturbance & & & 0.248 & & & 0.048 \\
\hline$(+)$ & $11(15.9)$ & $12(24.5)$ & & $13(9.3)$ & $14(18.7)$ & \\
\hline$(-)$ & $58(84.1)$ & $37(75.5)$ & & $127(90.7)$ & $61(81.3)$ & \\
\hline Tinnitus & & & 0.631 & & & 0.630 \\
\hline$(+)$ & $13(18.8)$ & $11(22.4)$ & & $14(10.0)$ & $6(8.0)$ & \\
\hline$(-)$ & $56(81.2)$ & $38(77.6)$ & & $126(90.0)$ & $69(92.0)$ & \\
\hline Hyperacusis & & & $\mathrm{N} / \mathrm{A}$ & & & $\mathrm{N} / \mathrm{A}$ \\
\hline$(+)$ & $0(0.0)$ & $2(4.1)$ & & $5(3.6)$ & $1(1.3)$ & \\
\hline$(-)$ & $69(100.0)$ & 47 (95.9) & & $135(96.4)$ & $74(98.7)$ & \\
\hline Vertigo & & & 0.777 & & & 0.970 \\
\hline$(+)$ & $14(20.3)$ & $11(22.4)$ & & $11(7.9)$ & $6(8.0)$ & \\
\hline$(-)$ & $55(79.7)$ & $38(77.6)$ & & $129(92.1)$ & $69(92.0)$ & \\
\hline Postauricular pain & & & 0.179 & & & 0.297 \\
\hline$(+)$ & $41(59.4)$ & $35(71.4)$ & & $49(35.0)$ & $21(28.0)$ & \\
\hline$(-)$ & $28(40.6)$ & $14(28.6)$ & & $91(65.0)$ & $54(72.0)$ & \\
\hline
\end{tabular}

Data are presented as $n$ (\%). RHS, Ramsay Hunt syndrome; BP, Bell's palsy; N/A, not applicable

Table 3. Associations between favorable recovery and otologic symptoms in patients with RHS and BP

\begin{tabular}{|c|c|c|c|c|c|c|}
\hline & & $\mathrm{HSS}(\mathrm{n}=118)$ & & & $B P(n=215)$ & \\
\hline & $\begin{array}{c}\text { Favorable } \\
\text { recovery } \\
(n=93)\end{array}$ & $\begin{array}{c}\text { Unfavorable } \\
\text { recovery } \\
(n=25)\end{array}$ & p-value & $\begin{array}{c}\text { Favorable } \\
\text { recovery } \\
(n=177)\end{array}$ & $\begin{array}{c}\text { Unfavorable } \\
\text { recovery } \\
(n=38)\end{array}$ & p-value \\
\hline Hearing disturbance & & & 0.284 & & & $>0.999$ \\
\hline$(+)$ & $17(18.3)$ & $7(28.0)$ & & $22(12.4)$ & $4(10.5)$ & \\
\hline$(-)$ & $76(81.7)$ & $18(72.0)$ & & $155(87.6)$ & $34(89.5)$ & \\
\hline Tinnitus & & & 0.284 & & & 0.539 \\
\hline$(+)$ & $17(18.3)$ & $7(28.0)$ & & $18(10.2)$ & $2(5.3)$ & \\
\hline$(-)$ & $76(81.7)$ & $18(72.0)$ & & $159(89.8)$ & $36(94.7)$ & \\
\hline Hyperacusis & & & N/A & & & N/A \\
\hline$(+)$ & $1(1.1)$ & $1(4.0)$ & & $6(3.4)$ & $0(0.0)$ & \\
\hline$(-)$ & $92(98.9)$ & $24(96.0)$ & & $171(96.6)$ & $38(100.0)$ & \\
\hline Vertigo & & & 0.136 & & & 0.510 \\
\hline$(+)$ & $17(18.3)$ & $8(32.0)$ & & $13(7.3)$ & $4(10.5)$ & \\
\hline$(-)$ & $76(81.7)$ & $17(68.0)$ & & $164(92.7)$ & $34(89.5)$ & \\
\hline Postauricular pain & & & 0.673 & & & 0.447 \\
\hline$(+)$ & $59(63.4)$ & $17(68.0)$ & & $60(63.4)$ & $10(68.0)$ & \\
\hline$(-)$ & $34(36.6)$ & $8(32.0)$ & & $117(36.6)$ & $28(32.0)$ & \\
\hline
\end{tabular}

Data are presented as $n$ (\%). RHS, Ramsay Hunt syndrome; BP, Bell's palsy; N/A, not applicable

\section{고 찰}

벨마비는 원인을 알 수 없는 안면마비로 뇌 병변, 외상 등 다른 원인들이 배제되고 진단되며, 갑작스러운 발병을 특징 으로 한다. 벨마비의 원인으로 가장 많이 거론되는 것은 단 순포진바이러스지만 아직까지 이에 대한 확증은 되지 않았 다. 이성대상포진은 수두대상포진바이러스의 재활성화(reac- tivation)에 의해 발병되는 것으로 알려져 있고, 귀와 안면부 에 홍반성 수포발진이 동반될 수 있는 등 일반적으로 벨마비 와는 다른 임상적 양상을 보인다. 하지만 두 질환 모두 심각 한 이통, 안면통 등을 동반할 수 있으며, 이외에도 이명, 청력 상실, 오심, 구토, 현기증, 안진 등과 같은 다른 동반되는 증상 도 있을 수 있다고 알려져 있다. ${ }^{78)}$ 안면마비에 동반되는 이런 주관적인 증상들은 안면마비 증상의 부차적인 것들로 여겨 
Table 4. Associations between otologic symptoms and other diseases (hypertension, diabetes, obesity, dyslipidemia) in patients with peripheral facial palsy

\begin{tabular}{|c|c|c|c|c|c|c|c|c|c|}
\hline \multicolumn{5}{|c|}{ Ramsay Hunt syndrome $(n=118)$} & \multicolumn{5}{|c|}{ Bell's palsy $(n=215)$} \\
\hline $\begin{array}{l}\text { Multivariate Logistic } \\
\text { regression analysis }\end{array}$ & $\mathrm{n}(\%)$ & OR & $95 \% \mathrm{Cl}$ & $p$-value & $\begin{array}{l}\text { Multivariate Logistic } \\
\text { regression analysis }\end{array}$ & $\mathrm{n}(\%)$ & OR & $95 \% \mathrm{Cl}$ & $p$-value \\
\hline \multicolumn{5}{|c|}{ Hearing disturbance $(n=24)$} & \multicolumn{5}{|c|}{ Hearing disturbance $(n=26)$} \\
\hline Hypertension & $3(12.5)$ & 0.25 & $0.04-1.53$ & 0.132 & Hypertension & $11(42.3)$ & 2.38 & $0.78-7.28$ & 0.128 \\
\hline Diabetes & $8(33.3)$ & 8.22 & $1.78-38.00$ & 0.007 & Diabetes & $11(42.3)$ & 4.79 & $1.64-14.02$ & 0.004 \\
\hline Dyslipidemia & $10(41.7)$ & 1.67 & $0.57-4.88$ & 0.357 & Dyslipidemia & $8(30.8)$ & 0.51 & $0.20-1.32$ & 0.561 \\
\hline Obesity & $9(37.5)$ & 0.97 & $0.31-2.98$ & 0.952 & Obesity & $8(30.8)$ & 0.75 & $0.29-1.96$ & 0.165 \\
\hline Age $($ mean $=50.92)$ & & 1.02 & $0.99-1.05$ & 0.271 & Age $($ mean $=48.54)$ & & 0.99 & $0.97-1.02$ & 0.682 \\
\hline \multicolumn{5}{|l|}{ Tinnitus $(n=24)$} & \multicolumn{5}{|l|}{ Tinnitus $(n=20)$} \\
\hline Hypertension & $1(4.2)$ & 0.66 & $0.06-7.28$ & 0.737 & Hypertension & $5(25.0)$ & 0.82 & $0.23-2.91$ & 0.762 \\
\hline Diabetes & $0(0.0)$ & 0.00 & $0.00-0.00$ & 0.998 & Diabetes & $6(30.0)$ & 2.70 & $0.81-9.00$ & 0.106 \\
\hline Dyslipidemia & $5(20.8)$ & 0.51 & $0.16-1.67$ & 0.268 & Dyslipidemia & $8(40.0)$ & 0.94 & $0.35-2.49$ & 0.893 \\
\hline Obesity & $4(16.7)$ & 0.59 & $0.17-2.02$ & 0.398 & Obesity & $6(30.0)$ & 0.80 & $0.29-2.24$ & 0.670 \\
\hline Age $($ mean $=46.79)$ & & 1.02 & $0.99-1.05$ & 0.143 & Age $($ mean $=46.80)$ & & 1.00 & $0.98-1.03$ & 0.812 \\
\hline \multicolumn{5}{|l|}{ Vertigo $(n=25)$} & \multicolumn{5}{|l|}{ Vertigo $(n=17)$} \\
\hline Hypertension & $3(12.0)$ & 0.59 & $0.12-3.03$ & 0.529 & Hypertension & $4(23.5)$ & 0.74 & $0.17-3.20$ & 0.687 \\
\hline Diabetes & $5(20.0)$ & 2.20 & $0.53-9.23$ & 0.280 & Diabetes & $6(35.3)$ & 5.36 & $1.39-20.57$ & 0.015 \\
\hline Dyslipidemia & $9(36.0)$ & 1.46 & $0.52-4.12$ & 0.477 & Dyslipidemia & $5(29.4)$ & 0.59 & $0.19-1.86$ & 0.369 \\
\hline Obesity & $6(24.0)$ & 0.53 & $0.17-1.67$ & 0.277 & Obesity & $3(17.6)$ & 0.37 & $0.10-1.38$ & 0.138 \\
\hline Age $($ mean $=49.20)$ & & 1.02 & $0.99-1.05$ & 0.271 & Age $($ mean $=44.47)$ & & 0.99 & $0.96-1.03$ & 0.721 \\
\hline \multicolumn{5}{|l|}{ Postauricular pain $(n=76)$} & \multicolumn{5}{|c|}{ Postauricular pain $(n=70)$} \\
\hline Hypertension & $8(10.5)$ & 0.47 & $0.10-2.22$ & 0.432 & Hypertension & $14(20.0)$ & 0.69 & $0.30-1.61$ & 0.396 \\
\hline Diabetes & $13(17.1)$ & 4.76 & $0.95-23.85$ & 0.058 & Diabetes & $14(20.0)$ & 1.83 & $0.77-4.33$ & 0.172 \\
\hline Dyslipidemia & $20(26.3)$ & 0.59 & $0.24-1.45$ & 0.220 & Dyslipidemia & $21(30.0)$ & 0.51 & $0.27-0.97$ & 0.039 \\
\hline Obesity & $20(26.3)$ & 0.76 & $0.30-1.91$ & 0.557 & Obesity & $18(25.7)$ & 0.65 & $0.34-1.25$ & 0.198 \\
\hline Age $($ mean=44.75) & & 1.00 & $0.97-1.02$ & 0.673 & Age $($ mean=44.81 $)$ & & 1.01 & $0.99-1.03$ & 0.361 \\
\hline
\end{tabular}

OR, odds ratio; $\mathrm{Cl}$, confidence Interval

지며, 증상들을 조절하기 위해 주로 대증적 치료가 행해진다. 안면마비 환자에게 이런 증상들이 동반되는 것은 상당한 스 트레스를 주는데, 이는 이런 증상들 자체가 주는 불편함과 더불어 이런 증상이 동반되는 환자들이 본인의 안면마비에 대한 예후가 더 나쁠 것이라 간주하는 경향이 있기 때문으로 생각된다. 하지만 아직까지 안면마비 환자들이 호소하는 이 런 주관적인 증상과 예후와의 관계는 많은 연구가 진행되어 있지 않았고 기존 연구들도 이견이 많은 실정이다.

이제까지 안면마비의 예후를 알기 위한 많은 연구들이 진 행되어 왔다. 현재까지 안면마비 환자의 예후를 알아보는 대 표적인 방법들로 신경전도검사와 근전도검사 등의 신경생리 학적 검사들이 시행되고 있고, 비교적 마비의 정도와 회복률 을 예상하는 데 좋은 검사법으로 알려져 있다. 하지만, 이런 신경생리학적 검사들은 안면마비가 발생한지 일정 시간이 지 나야 시행할 수 있고, 많은 병원에서 제대로 장비가 갖춰져 있지 않을 뿐더러 비용적인 측면도 환자에게 부담이 된다. 그 래서 빠른 시기에 간단한 방법으로 안면마비 환자의 예후를
예측하기 위한 다른 검사법들에 대한 연구들이 진행되고 있 다. 최근에는 혈액검사에서 나오는 염증 관련 수치로 이성대 상포진 환자의 예후를 빠르게 예측할 수 있는 방법이 소개되 기도 하였다. ${ }^{13)}$ 본 연구에서도 안면마비 환자의 예후를 예측 할 수 있는 다른 방법을 찾으려 시도했다. 신경생리학적 검사 나 혈액학적 검사와 같이 비교적 객관적인 지표가 아닌 환자 가 호소하는 주관적인 증상으로 연구를 진행하였기에 자료의 편향(bias)이 있을 수 있다는 한계점이 있다. 또한 안면마비 환자가 호소하는 이과적 증상들이 예후와 관련이 없다는 결 과가 나와, 안면마비 환자의 예후를 예측하기 위한 다른 방법 을 발견하지 못했다. 그러나 안면마비의 동반증상들에 관한 연구가 많이 진행되지 않았고 진행된 연구도 일부 인자만 연 구되었거나 명확하지 않기에, 많은 수의 안면마비 환자의 이 과적 증상을 정리하고 분석했다는 데에 본 연구는 의의가 있 다. 추후 이과적 증상들을 더 구체적으로 세분화하여 안면마 비 환자의 증상들과 예후와의 관계에 대해 추가적 연구가 필 요할 것이다. 또한 이런 주관적인 증상들에 대해서 순음청력 
검사(pure tone audiometry), 이명장애지수(Tinnitus Handicap Inventory), 비디오안진검사(videonystagmography) 등 의 검사를 적극적으로 시행하여 객관화된 지표를 얻는다면 보다 정략적인 분석이 가능할 것이다.

Wayman 등 ${ }^{44}$ 은 이성대상포진 환자에서 청력저하, 이명, 청 각과민, 어지러움 등이 동반될 수 있는데, 이 중 청각과민과 안면마비의 심각성 정도는 아무런 관련이 없고, 후미로성 난 청(retrocochlear hearing loss), 심각한 난청, 어지러움 등은 안면마비에 좋지 않은 영향을 준다고 보고하였다. Adour ${ }^{7)}$ 에 의하면 안면마비 환자에서 청력 감소가 동반될 수 있고, 안면 마비의 중증도와 청력 감소의 정도가 비례하고 어지러움이 없을 때 예후가 좋다고 하였다. 이는 단순포진바이러스나 수 두대상포진바이러스가 안면신경(facial nerve) 뿐만 아니라 전 정와우신경(vestibulocochlear nerve)에도 영향을 준다는 것 을 시사한다. 본 연구에서는 벨마비 환자들 중 House-Brackmann grade $\mathrm{V}$ 이상의 severe facial palsy가 House-Brackmann grade IV 이하의 moderate facial palsy보다 청력저하 를 더 많이 호소하는 결과가 나와 안면마비의 정도와 청력 감 소가 상관관계가 있음을 시사하였다. 다만, 모든 환자에서 안 면마비 전후의 객관적인 순음청력검사 결과를 얻을 수 없어 실제로 청력이 감소하였는지는 알 수 없었다. 한편, 청력 저하 를 호소하는 환자들 중 실제로 순음청력검사상 청력 저하 소 견이 보이지 않은 환자들도 있어 심한 안면마비로 인해 환자 의 불안감이 증가되고, 이로 인해 잘못된 감각이 인지되지 않 을까 하는 추측해 볼 수 있다. 만약 그렇다면 심한 안면마비 환자들에게 정신적 고통을 경감시켜 주기 위한 치료도 병행 되어야 할 것이다.

갑작스러운 난청이 생기는 돌발성 난청과 안면마비가 동시 에 생긴다면 뇌병변을 의심해봐야 한다. 뇌병변이 있는 환자 들은 본 연구에서 제외되었다. 또한 돌발성 난청과 말초성 안 면마비와의 상관관계는 본 연구에서 밝히지 않았다. 따라서 객관적 청력 감소가 안면마비의 심각성이나 예후 등에 영향 을 준다는 결과는 본 연구에서는 알 수 없었다.

Peitersen ${ }^{15)}$ 의 연구에 따르면 벨마비 환자들의 예후는 미각 (taste), 등자골반사(stapedial reflex), 눈물 흘림(tearing) 등 이 관련있다고 한다. 정상적인 안면신경의 기능들이 유지될 때, 후이개 통증이 없고 마비의 정도가 심하지 않을수록 예 후가 좋다고 하였다. 하지만 이런 기존의 연구와 다르게 우리 연구에서는 벨마비와 이성대상포진 모두 후이개 통증과 예후 와는 유의미한 상관관계가 없었다. 또한 청력 감소, 이명, 청 각과민, 어지러움 등 안면마비 환자들이 호소할 수 있는 증상 역시 예후와 관계가 없었다. 앞서 언급한 바와 같이 단순포진 바이러스나 수두대상포진바이러스가 안면신경 뿐만 아니라
전정와우신경에도 영향을 줄 것으로 생각되어, 일반적으로 이런 청력 증상과 어지러움을 동반하면 심한 안면마비로 생 각할 수 있어 예후도 안 좋을 것 같지만 우리 연구에서는 달 랐다. 이에 대한 원인으로 단순포진바이러스와 수두대상포진 바이러스의 신경 침범 정도가 안면마비의 중증도와 큰 연관 이 없을 수도 있기 때문일 것으로 추측해 볼 수 있다. 이는 단 순포진바이러스, 수두대상포진바이러스 각각은 신경을 침범 하는 방식이 다양한데, 그로 인해 안면마비의 임상적 발현이 다르게 나타나기 때문일 수도 있다. ${ }^{16,17)}$ 안면마비에서 이런 현 상들이 왜 일어나는지에 대한 병태생리학(pathophysiology) 에 대한 추가적인 연구가 필요할 것이다.

당뇨, 고혈압 등 동반질환이 안면마비의 예후에 영향을 끼 친다는 연구들이 있다. ${ }^{18,19)}$ 이는 vascular insufficiency가 조 직들의 대사(metabolism)를 저하시키고 산화적 손상(oxidative injury)을 끼치는 등, 안면 신경의 회복을 더디게 만드는 원인이라고 생각할 수 있다. 이렇듯 당뇨, 고혈압 등 동반질환 이 안면마비의 예후에 영향을 끼치지만, 안면마비 환자에서 청력 증상, 통증, 어지러움 등에 어떤 영향을 미치는 지에 대 한 명확한 결론은 없다. 우리는 이 연구를 통해 안면마비 환 자가 가지고 있는 고혈압, 당뇨 등의 질환들이 청력저하, 어지 러움 등의 증상들을 더 잘 유발시킬 수 있다는 결과를 얻었 다. 최근 연구에 따르면 당뇨, 고혈압 등의 질환들이 인체의 면역시스템에 영향을 줄 수 있는데, 이런 질환들은 단순포진 바이러스, 수두대상포진바이러스 감염에도 악영향을 끼친다 고 생각된다. ${ }^{20)}$ 따라서 이런 질환들을 가지고 있지 않은 안면 마비 환자들에 비해 이런 질환을 가지고 있는 안면마비 환자 들이 단순포진바이러스나 수두대상포진바이러스의 전정와우 신경 감염에 취약할 것이다. 또한 본 연구에서 안면마비 환자 의 이상지질혈증과 후이개 통증의 연관성을 찾을 수 있었다. 이상지질혈증은 허리 통증이나 무릎 통증 등 다양한 통증과 관련이 있다는 연구 결과들이 발표되었다. ${ }^{21,22)}$ 이상지질혈증 이 혈관 건강을 악화시키고 바이러스에 의한 염증반응에 악 영향을 끼치는 등 다양한 경로로 안면마비 환자의 통증에 관 여할 것이라는 추측을 해볼 수 있다. 안면마비에 동반되는 다 양한 이과적 증상들은 환자에게 불안감을 증폭시키고 환자 에게 더 많은 스트레스를 주기에 안면마비 환자에게 있어 고 혈압, 당뇨, 이상지질혈증 등의 만성질환의 관리가 예후뿐만 아니라 환자의 삶의 질을 높이는 데에도 도움이 된다는 것을 시사한다.

앞서 언급하였지만 본 연구의 제한점은 환자의 주관적인 증상을 바탕으로 연구를 진행하였다는 것이다. 객관적으로 측정된 순음청력검사나 전정기능검사 등을 시행하여 안면마 비의 심각성이나 예후 등과 비교하지 않았다. 기존의 연구들 
은 대부분 신경생리학적인 검사, 혈액학적 검사 등과 환자의 예후와의 관계를 연구하였지만, 이과적 증상과 예후와의 관 계를 본 연구는 거의 없었다. 추후 주관적인 증상 호소와 객 관적인 검사 등과 안면마비의 심각성, 예후 등을 비교한다면 더 의미있는 결과가 도출될 수 있으리라 생각한다.

또한, 본 연구는 후향적 연구로, 고혈압, 당뇨병 등을 진단 받은 것을 기준으로 진행되었기에 현병력과 과거력을 가능하 면 자세히 파악하려고 노력하였지만 환자들의 정확한 건강 상태를 모두 파악할 수 없었다. 본 연구에 포함된 환자들 중 안면마비로 입원해서 고혈압이나 당뇨병이 처음 진단된 환 자, 기존에 이런 질환들로 약을 복용하는 환자도 있었고, 드 물게는 진단받았지만 약을 복용하지 않은 환자도 있었다. 또, 신장질환, 심장질환, 내분비질환 등과 같은 다른 질환 때문에 혈압이나 당뇨가 조절 안되는 환자도 있었다. 그리고 많은 환 자들이 가정에서 혈압과 당을 측정하지 않는 경우가 있어 기 존에 혈압이나 당뇨가 잘 조절되고 있었는지 파악할 수 없었 다. 따라서 조절되지 않은 혈압이나 당뇨가 안면마비에 어떤 영향을 미치는지에 대해서는 정확히 알 수 없었다. 이런 한계 점들을 보완하기 위해 추후에는 전향적 연구가 필요할 것이 다. 향후 연구에서는 안면마비 환자들이 병원에 내원하였을 때 기저질환에 대해 더 관심을 갖고 자세히 문진하고 세심히 의무기록을 검토할 예정이다. 고혈압, 당뇨 등의 환자들에게 이전의 혈압, 당 수치 등의 기록을 확인하고, 그 질환들로 어 떤 약들을 복용하고 있는지, 또 그에 대한 진료 기록 등을 확 인하여 기록한다면 추후 안면마비의 예후와 발병 등에 관한 연구 뿐만 아니라 임상에서 안면마비 환자의 진료를 볼 때도 도움이 될 것이다.

결론적으로, 청력저하, 이명, 어지러움, 후이개 통증 등 이과 적 증상은 벨마비 환자보다 이성대상포진 환자에서 더 많이 나타났다. 말초성 안면마비 환자 전체를 고려했을 때 이과적 증상과 예후와는 연관성이 없었고, 벨마비 환자에서 안면마 비의 정도가 심할수록 여러 이과적 증상 중 청력저하를 호소 하는 환자가 많았다. 또한 안면마비 환자들 중 고혈압이 있을 때 청력저하를 더 많이 호소하였고, 당뇨가 있을 때 청력저 하를 더 많이 호소하고 어지러움이 더 많이 발생하였고, 이상 지질혈증이 있을 때 후이개 통증을 더 많이 호소하였다. 이과 적 증상이 말초성 안면마비 환자의 예후와는 연관이 없지만, 이과적 증상의 발현을 줄여 환자의 추가적인 스트레스를 줄 이기 위해 고혈압, 당뇨, 이상지질혈증 등의 만성질환의 관리 가 중요하다.

\section{Acknowledgments}

This work was supported by the National Research Foundation of Korea (NRF) grant funded by the Korea Government (NRF-

\section{R1A6A1A03025124).}

\section{Author Contribution}

Conceptualization: Soo Young Choi, Sang Hoon Kim, Seung Geun Yeo. Data curation: Soo Young Choi. Formal analysis: Soo Young Choi, Gang Won Choi, Hyun Ji Lee. Investigation: Soo Young Choi, Jae Min Lee. Methodology: Tong In Oh, Eun Hye Lee. Project administration: Seung Geun Yeo. Software: Tong In Oh, Jae Min Lee. Supervision: Sang Hoon Kim, Seung Geun Yeo. Validation: Tong In Oh, Eun Hye Lee. Visualization: Gang Won Choi, Hyun Ji Lee. Writing — original draft: Soo Young Choi. Writingreview \& editing: Seung Geun Yeo.

\section{ORCIDs}

Seung Geun Yeo https://orcid.org/0000-0001-8021-1024

Soo Young Choi https://orcid.org/0000-0003-2056-4797

Tong In Oh https://orcid.org/0000-0003-3820-0107

Eun Hye Lee https://orcid.org/0000-0002-8903-8528

Sang Hoon Kim https://orcid.org/0000-0001-5045-5060

\section{REFERENCES}

1) Zainine R, Sellami M, Charfeddine A, Beltaief N, Sahtout S, Besbes G. Ramsay Hunt syndrome. Eur Ann Otorhinolaryngol Head Neck Dis 2012;129(1):22-5.

2) Sullivan FM, Swan IR, Donnan PT, Morrison JM, Smith BH, McKinstry B, et al. Early treatment with prednisolone or acyclovir in Bell's palsy. N Engl J Med 2007;357(16):1598-607.

3) Peitersen E. The natural history of Bell's palsy. Am J Otol 1982; 4(2):107-11

4) Peitersen E. Natural history of Bell's palsy. Acta Otolaryngol Suppl 1992;492:122-4.

5) Devriese PP, Moesker WH. The natural history of facial paralysis in herpes zoster. Clin Otolaryngol Allied Sci 1988;13(4):289-98.

6) Ikeda M, Abiko Y, Kukimoto N, Omori H, Nakazato H, Ikeda K. Clinical factors that influence the prognosis of facial nerve paralysis and the magnitudes of influence. Laryngoscope 2005;115(5):85560.

7) Adour KK. Otological complications of herpes zoster. Ann Neurol 1994;35 Suppl:S62-4.

8) Byl FM, Adour KK. Auditory symptoms associated with herpes zoster or idiopathic facial paralysis. Laryngoscope 1977;87(3):372-9.

9) Yeo SW, Lee DH, Jun BC, Chang KH, Park YS. Analysis of prognostic factors in Bell's palsy and Ramsay Hunt syndrome. Auris Nasus Larynx 2007;34(2):159-64.

10) Zimmet P, Alberti KG, Kaufman F, Tajima N, Silink M, Arslanian $\mathrm{S}$, et al. The metabolic syndrome in children and adolescents - an IDF consensus report. Pediatr Diabetes 2007;8(5):299-306.

11) Grundy SM, Cleeman JI, Daniels SR, Donato KA, Eckel RH, Franklin BA, et al. Diagnosis and management of the metabolic syndrome: An American Heart Association/National Heart, Lung, and Blood Institute Scientific Statement. Circulation 2005;112(17): 2735-52.

12) Ford ES, Giles WH, Dietz WH. Prevalence of the metabolic syndrome among US adults: Findings from the third National Health and Nutrition Examination Survey. JAMA 2002;287(3):356-9.

13) Soh Y, Lee JH, Jung J, Dong SH, Byun JY, Park MS, et al. A high neutrophil-to-lymphocyte ratio is associated with recovery from Ramsay Hunt syndrome. ORL J Otorhinolaryngol Relat Spec 2019; 81(2-3):130-7

14) Wayman DM, Pham HN, Byl FM, Adour KK. Audiological manifestations of Ramsay Hunt syndrome. J Laryngol Otol 
1990;104(2):104-8.

15) Peitersen E. Bell's palsy: The spontaneous course of 2,500 peripheral facial nerve palsies of different etiologies. Acta Otolaryngol Suppl 2002;(549):4-30.

16) Agelidis AM, Shukla D. Cell entry mechanisms of HSV: What we have learned in recent years. Future Virol 2015;10(10):1145-54.

17) Kleinschmidt-DeMasters BK, Gilden DH. Varicella-Zoster virus infections of the nervous system: Clinical and pathologic correlates. Arch Pathol Lab Med 2001;125(6):770-80.

18) Ryu EW, Lee HY, Lee SY, Park MS, Yeo SG. Clinical manifestations and prognosis of patients with Ramsay Hunt syndrome. Am J Otolaryngol 2012;33(3):313-8.
19) Adour KK, Wingerd J. Idiopathic facial paralysis (Bell's palsy): Factors affecting severity and outcome in 446 patients. Neurology 1974;24(12):1112-6.

20) Andersen CJ, Murphy KE, Fernandez ML. Impact of obesity and metabolic syndrome on immunity. Adv Nutr 2016;7(1):66-75.

21) Zhou M, Guo Y, Wang D, Shi D, Li W, Liu Y, et al. The crosssectional and longitudinal effect of hyperlipidemia on knee osteoarthritis: Results from the Dongfeng-Tongji cohort in China. Sci Rep 2017;7(1):9739.

22) Heuch I, Heuch I, Hagen K, Zwart JA. Associations between serum lipid levels and chronic low back pain. Epidemiology 2010;21(6): 837-41. 